\title{
DETERMINATION OF THE MORPHOLOGY OF THE STARCH GRANULES AND THE OPTIMUM INTERNAL COOKING TEMPERATURE OF FOUR ANDEAN CROPS: OCA (OXALIS TUBEROSA MOLINA), OLLUCO (ULLUCUS TUBEROSUS LOZ), ISAÑO (TROPAEOLUM TUBEROSUM RUIZ \& PAVON) AND ARRACACHA (ARRACACIA XANTHORRHIZA BANCROFT)
}

\author{
- Research paper - \\ Omar BELLIDO-VALENCIA*11, Paul K. HUANCA-ZÚÑIGA**, Luis A. MEDINA- \\ MARROQUÍN* \\ * Department of Food Industry Engineering, Universidad Nacional de San Agustín, Arequipa, \\ Peru \\ ** Department of Materials Engineering, Universidad Nacional de San Agustín, Arequipa, \\ Peru
}

\begin{abstract}
Andean grains (i.e. quinoa, amaranth) have been increasingly studied in recent times, mainly due to the increase in international consumption. However, Andean tubers other than potatoes have not been so widespread and are mainly studied for their starch, previously extracted. This work studied the morphology of native starch in four of these crops (oca, olluco, isaño and aracacha), during cooking and the evolution of their internal temperature in relation to sensory acceptability. Using scanning electron microscopy, it was determined that the size of crude starch granules was between $9 \mu \mathrm{m}$ to $38.2 \mu \mathrm{m}$ for oca, 4.48 to $24.9 \mu \mathrm{m}$ for olluco, 4.45 to $22.9 \mu \mathrm{m}$ for isaño, and 5.36 to $23.8 \mu \mathrm{m}$ for arracacha. Sensorially, it was determined that the optimum cooking temperature for arracacha was $89.1^{\circ} \mathrm{C}, 90.9^{\circ} \mathrm{C}$ for oca, $91^{\circ} \mathrm{C}$ for isaño, and $91.4{ }^{\circ} \mathrm{C}$ for olluco. All samples had optimal cooking times shorter than potato, with the isaño having the best heat transfer.
\end{abstract}

Keywords: starch; scanning electron microscopy; cooking temperature; starch gelatinisation; andean tubers

\section{INTRODUCTION}

The Andean crops known today were domesticated by the first inhabitants of South America in the Andean countries, being cultivated at high altitude up to 4000 meters above sea level. Two of these crops (Zea mays subsp. mays and Solanum tuberosum L.) were subsequently widely disseminated, now representing a large part of the agricultural trade. However, there are edible tubers and tuberous roots that are underused and used mainly for consumption by farmers or traded in small markets, complementing potato cultivation (Bianco and Sachs, 1998; Flores et al., 2003). These include oca (Oxalis tuberosa Molina), olluco (Ullucus tuberosus Loz), isaño (Tropaeolum tuberosum Ruiz \& Pavon) and arracacha (Arracacia xanthorrhiza Bancroft). They present a great genetic diversity (Biondi et al., 2009), which is influenced by the place of origin and expressed in different morphology and heterogeneous varieties (Malice, 2009).

The tubers of oca are cylindrical or ovoid shaped, averaging 7 to $11 \mathrm{~cm}$ in length, those of olluco are usually elongated or curved with thin skin and little visible buds, while the tubers of isaño vary in color and shape (Flores et al., 2003). Arracacha is a tuberous root, the edible part of which is a long, cylindrical cormorous rhizome with horizontal knotted rings (Hodge, 1954), it is also called "Peruvian carrot".

Nutritional characteristics (King and Gershoff, 1987; Busch et al., 2000) and potential health benefits (Jimenez et al., 2015) of these crops have been studied, while their processing has been studied to a lesser extent, although with greater interest in recent years in processed foods such as porridges (Surco Laos, 2004), instant soups, baby food and fried foods

${ }^{1}$ Corresponding author. E-Mail address: obellido@unsa.edu.pe 
(Santos and Hermann, 1994). However, its main form of consumption has remained the same, i. e. culinary preparations.

Using differential scanning calorimetry (DSC), the starches from these crops have been studied to determine their point of gelatinisation after being extracted from the sample matrix (Santacruz, 2002; ValcárcelYamani et al., 2013, Cruz et al., 2016), and only in the case of oca and olluco the whole tubers were studied during cooking (Busch et

\section{MATERIALS AND METHODS}

Samples: The samples of the Andean products oca, olluco, isaño and arracacha were acquired in the district of Tomepampa,
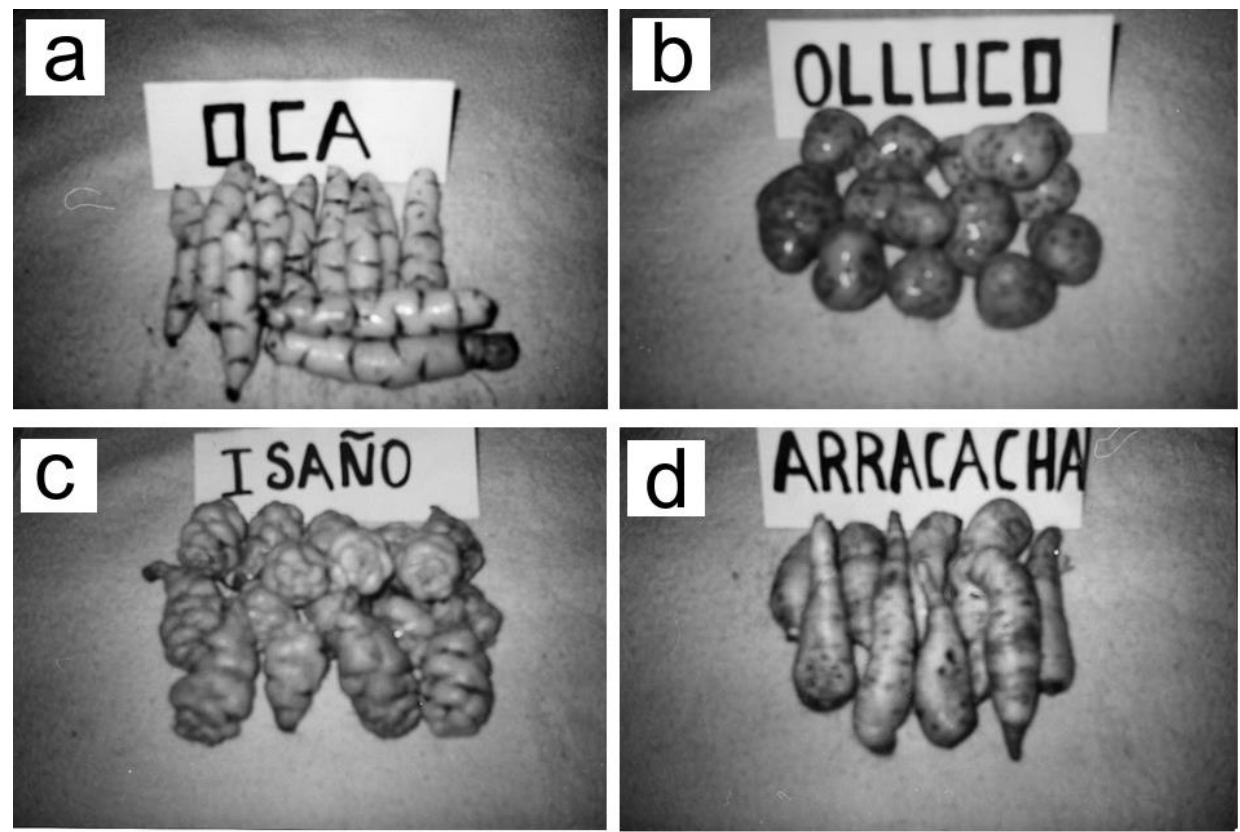

Figure 1. Samples of Andean tubers

Internal temperature evolution:The samples were put in a container containing potable water maintained at boiling temperature $(92.8$ $\left.{ }^{\circ} \mathrm{C}\right)$. Specimens were removed from each sample at certain time periods to measure the internal temperature in the geometric center using a digital penetration thermometer (Hanna Instruments Checkpoint I, USA).

Morphology of starch granules:Each sample removed from the boiling water was prepared for observation by electron microscopy. Each sample was cut into $3 \mathrm{~mm}$ thick slices. For each Andean crop, an uncooked (raw) control al., 2000; Goldner et al., 2012), so there is little knowledge of the gelatinisation process of native starch from isaño and arracacha, as well as the morphology of their starch granules during the cooking.

This work aims to determine the most suitable internal cooking temperature for the consumption of these four Andean crops by sensory evaluation, as well as to describe the morphology of the native starch granules of each product at different cooking times.

province of La Unión, in the region of Arequipa, Peru, and selected so that each sample was made up of specimens of similar size (Figure 1). 
Sensory evaluation and optimal cooking time: In a preliminary experiment, a cooking time range was determined for each product (from 26 to 29 minutes for the oca, 28 to 31 minutes for the olluco, 23 to 26 minutes for the isaño and from 26 to 29 minutes for the arracacha), within which it was expected to find the optimal time. The sensory evaluation was carried out using a panel of 10 members who evaluated the taste, appearance, acceptability and aroma, using a scoring test on a structured scale, comprising milestones from "not very intense" to "very intense". High values were

\section{RESULTS AND DISCUSSIONS}

\section{Internal temperature evolution}

The isaño and olluco samples had a similar behavior in their evolution of the internal temperature (Figure 2), while the oca and arracacha samples had a different and slower behavior. This may be due to the fact that the considered to be better from the consumer point of view. The samples were cooked with boiling water, making measurements in the geometric center with a thermocouple similar to the procedure of Goldner et al. (2012) but removing them at the determined times, then drained the water and cooled to room temperature before use (Busch et al., 2000).

The results of the sensory evaluation were treated by an analysis of variance (ANOVA) and the Tukey's test using the version 3.4.1 of the statistical programming language $\mathrm{R}$ ( $\mathrm{R}$ Development Core Team, 2008) .

arracacha is a tuberous root and not a tuber like the rest of the samples, as well as the shape and size of the samples that affect heat transfer. To the best knowledge of the authors, the internal temperature evolution of these crops has not been previously reported as it was for potatoes (Heinze, 1955)

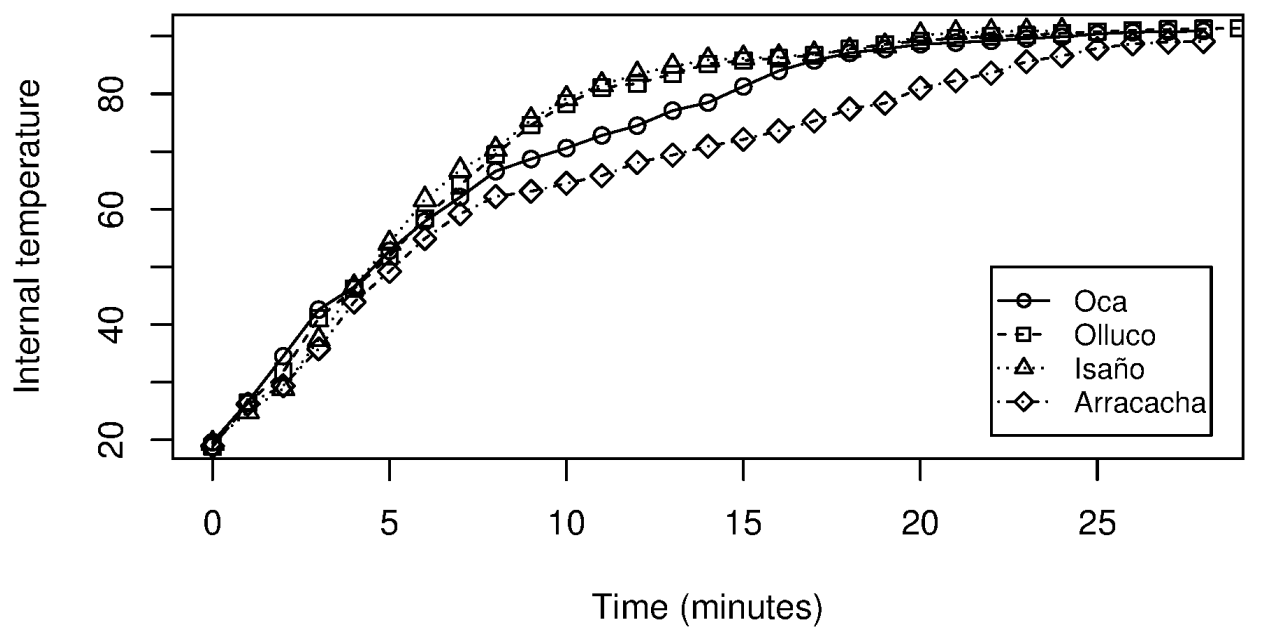

Figure 2. Evolution of the internal temperature of the four Andean crops

\section{Morphology of starch granules}

As Table 1 shows, with the start of cooking, the average size of the starch granules in all samples is increased by swelling of the granules. However, after 4 minutes of cooking the oca and olluco granules lost their definite shape, while those of isaño lost their shape after 5 minutes. Up to 5 minutes, the Arracacha granules had maintained their defined shape and continued to swell to an average of $18.85 \mu \mathrm{m}$.
The shape of the starch granules in raw oca samples was oval, as were the olluco, while the isaño and the arracacha were more diverse in the shape of their granules (Figure 3). The isaño starch granules were mainly oval shaped but with a small amount of irregular granules attached to others. In the case of the arracacha, granules with truncated and irregular shapes were observed. 
Table 1. Size of starch granules of by raw samples, in $\mu \mathrm{m}$

\begin{tabular}{|l|l|l|l|l|l|l|}
\hline \multirow{2}{*}{ Sample } & \multicolumn{3}{|c|}{ Raw } & \multicolumn{3}{c|}{ Cooking for 3 minutes } \\
\cline { 2 - 7 } & $\begin{array}{l}\text { Minimum } \\
\text { size }\end{array}$ & $\begin{array}{l}\text { Average } \\
\text { size }\end{array}$ & $\begin{array}{l}\text { Maximum } \\
\text { size }\end{array}$ & $\begin{array}{l}\text { Minimum } \\
\text { size }\end{array}$ & $\begin{array}{l}\text { Average } \\
\text { size }\end{array}$ & $\begin{array}{l}\text { Maximum } \\
\text { size }\end{array}$ \\
\hline Oca & 9.00 & 23.60 & 38.20 & 11.80 & 26.35 & 40.90 \\
\hline Olluco & 4.48 & 12.43 & 24.90 & 5.57 & 19.14 & 32.70 \\
\hline Isaño & 4.45 & 13.68 & 22.90 & 5.14 & 14.27 & 23.40 \\
\hline Arracacha & 5.36 & 14.58 & 23.80 & 5.67 & 15.79 & 25.90 \\
\hline
\end{tabular}

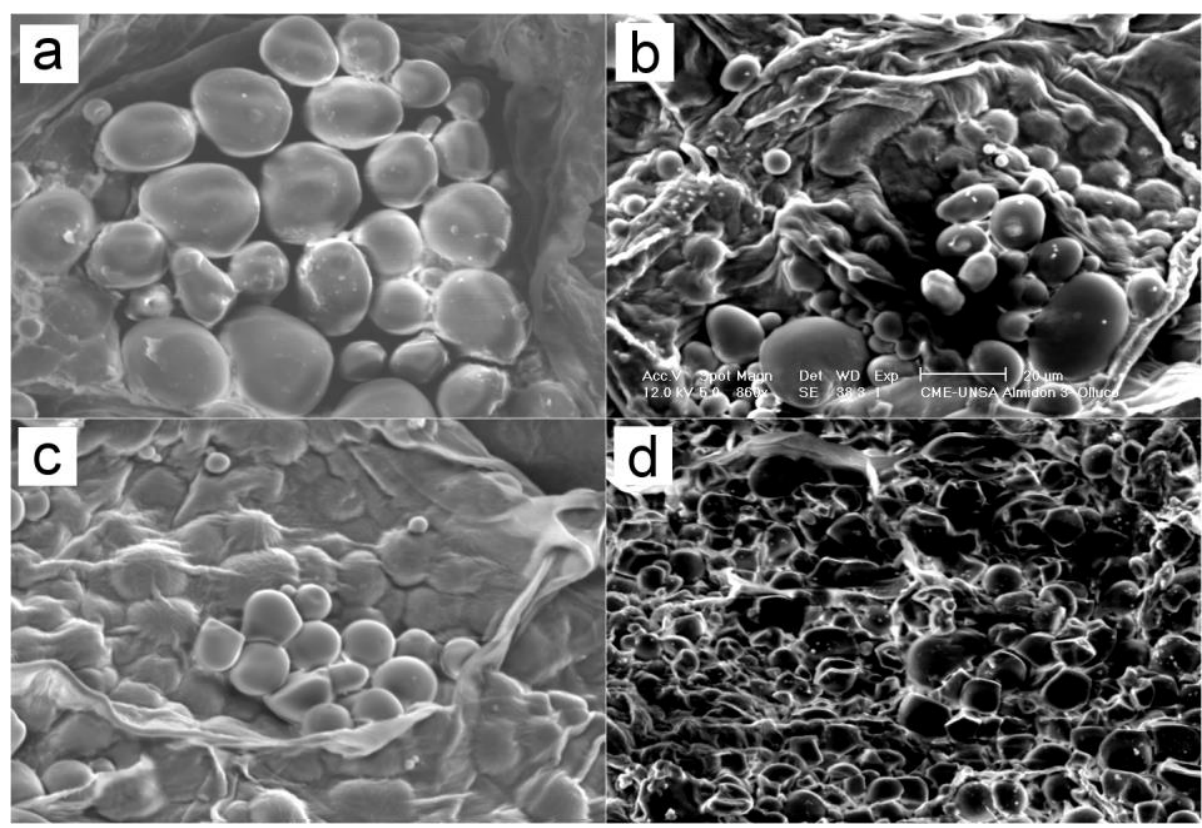

Figure 3. Micro-photographs of raw starch granules from a) Oca (866x), b) olluco (866x), c) isaño $(866 x)$ and $d)$ arracacha $(641 x)$

In a study on the morphology of the oca, olluco and isaño starch granules by scanning electron microscopy (SEM), two different types of starch grains were revealed: one small (less than $7 \mu \mathrm{m}$ ) and not very visible, similar and present in the three tubers; and another highly variable in size and shape (Cortella and Pochettino, 1995). This same bimodal distribution was confirmed by Torres et al. (2011) for the same samples using an inverted microscope. In this study, the smallest granule sizes corresponded to the olluco and isaño. Previously it was also reported that the size of the oca granules determined by SEM was 25 to $50 \mu \mathrm{m}$ with oval and elliptical shapes (Hernández-Lauzardo et al., 2004), similar to Santacruz (2002) (22 to $55 \mu \mathrm{m}$ ) and Santacruz (2004) (20 to $55 \mu \mathrm{m})$, representing a range of granules larger than those identified in this study for the oca, which were similar in diameter to what Valcárcel-Yamani et al.
(2013) reported for oca samples (6.99 to 24.41 $\mu \mathrm{m})$.

The size and shape of olluco starch granules were similar to the diameter determined by Valcárcel-Yamani et al. (2013) (5.68 to 23.18 $\mu \mathrm{m}$ in diameter and 6.45 to $32.64 \mu \mathrm{m}$ in length). Starch granules from the isaño and olluco were the smallest in the present study, although isaño granules were larger than those reported by the same authors, which indicated 4.39 to $16.29 \mu \mathrm{m}$ in length and 4.07 to 13.09 $\mu \mathrm{m}$ in diameter.

The size of Arracacha starch granules was in the range of 4 to $26 \mu \mathrm{m}$ reported by Pérez et al. (1999), whith a truncated egg shape. Similar range was reported by Santacruz (2002) and Santacruz (2004) (7 to $23 \mu \mathrm{m})$, which also noted the presence of pores in native Arracacha granules, with a diameter of about 2 $\mu \mathrm{m}$. These pores have not been identified in this study. A narrower size range (5 to $15 \mu \mathrm{m})$ was observed by Medina et al. (2012), where 
they suggest that cuboid and truncated forms may have originated during the starch extraction process, however our results revealed that these forms occur naturally in the samples without any processing in addition to moisture reduction. The average size of the starch granules of arracacha were close to that found for Brazilian varieties (from 11 to 14.7 $\mu \mathrm{m})$ (Rocha et al., 2008), where the smaller granules were those with more polyhedral or polygonal shapes. The same authors point out that the difference in size between granules may be due to the use of plants of different varieties, ages or harvesting times, or to different size measurement methodologies.

Optical microscopy revealed that the starch granules of the oca, olluco and isaño were found to be elliptical, triangular and globular in shape with an average size of 30,15 and 10 $\mu \mathrm{m}$ respectively (Surco Laos, 2004). When the arracacha granules were observed by optical microscopy, they had a polyhedral shape with a size range of 2 to $20 \mu \mathrm{m}$, representing more than $40 \%$ of the granules from 5 to $8 \mu \mathrm{m}$ (Quiroga Ledezma, 2009). Using an inverted microscope, Feret diameter for the oca was determined as $22.9 \pm 21.8 \mu \mathrm{m}$ with irregularly shaped granules, for the olluco it was $18 \pm 9$ $\mu \mathrm{m}$ with irregularly shaped granules, for the isaño it was $11.4 \pm 7.1 \mu \mathrm{m}$ and for the arracacha it was $10.8 \pm 5.7 \mu \mathrm{m}$, with polygonal shaped granules (Torres et al., 2011).

Using the laser light scattering technique, it is reported that the olluco starch granules showed a coma-like shape, with a bulge at one end, while the oca granules were elliptical in shape. The mean diameter over volume of the olluco starch granules was $23.30 \mu \mathrm{m}$, while the oca was $29.90 \mu \mathrm{m}$ (Cruz et al., 2016). Our results have not allowed us to confirm this comma-like shape of the olluco granules (Figure 3).

The oca and olluco starch granules swelled, lost their oval and slightly elongated shape with the cooking time (Figures 4 and 5). After 3 minutes they develop irregular shapes and form pastes were seen in the background of the vascular bundles or supporting tissue of the samples. The presence of clumped starch granules that were separated into pieces in Figure 5 was also reported by Rocha et al. (2011).

The isaño pellets began to disintegrate due to swelling after 4 minutes (Figure 6) while the Arracacha granules began to disintegrate after 5 minutes (Figure 7). In both cases, as with the oca and the olluco, they began to form pastes. Arracacha starch gels were considered more stable at freeze-thaw cycles, being harder than modified and waxy corn starches (Takeiti et al., 2007), for which they would represent an alternative because of their $4 \%$ amylose content (Santacruz, 2002) and equal resistance to overcooking as potato starch (Rocha et al., 2011).

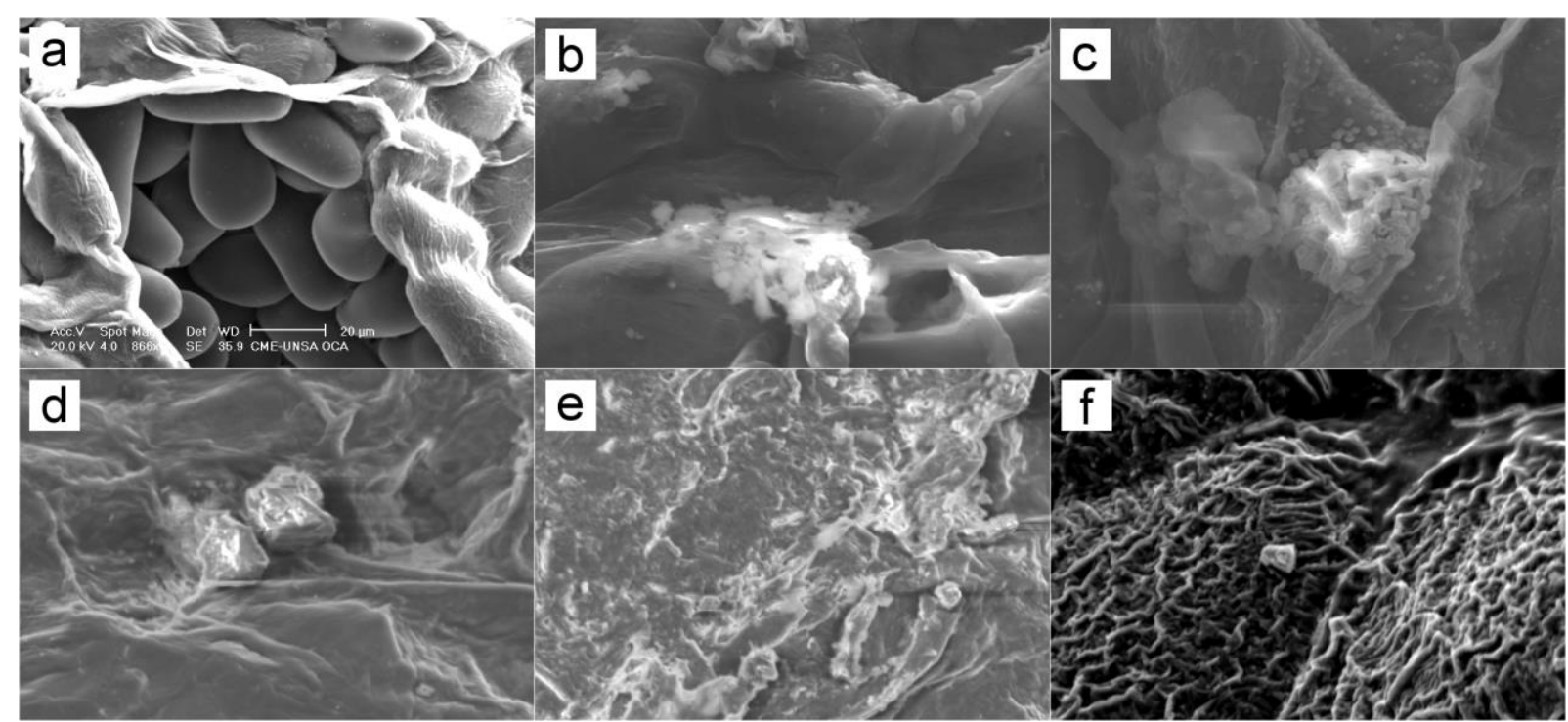

Figure 4. Microphotographs of the oca starch granules after a) 3, b) 4, c) 10, d) 14, e) 22 and f) 28 minutes 


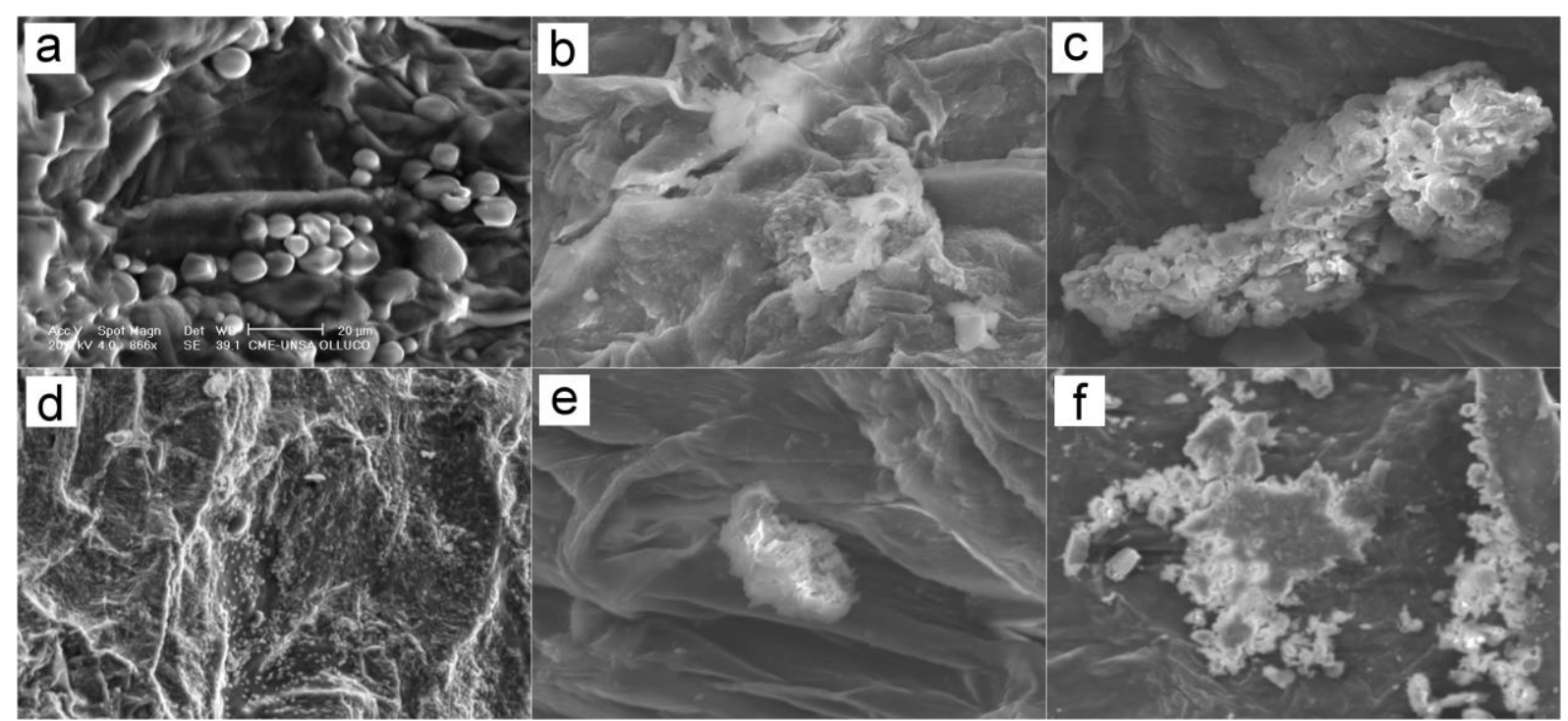

Figure 5. Microphotographs of the olluco starch granules after a) 3, b) 4, c) 10, d) 15, e) 19 and f) 29 minutes

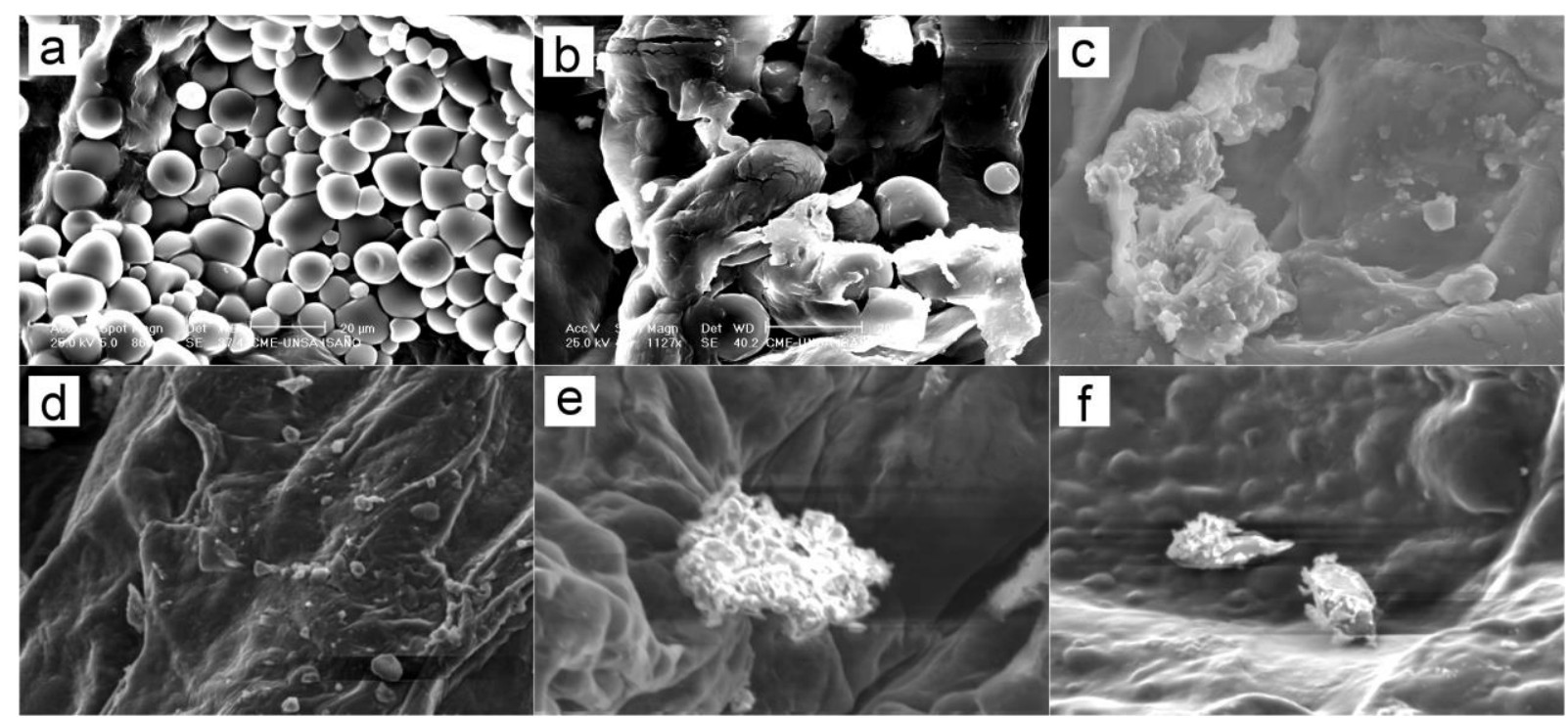

Figure 6. Micro-photographs of isaño starch granules after a) 3, b) 4, c) 5, d) 6, e) 19 and f) 24 minutes

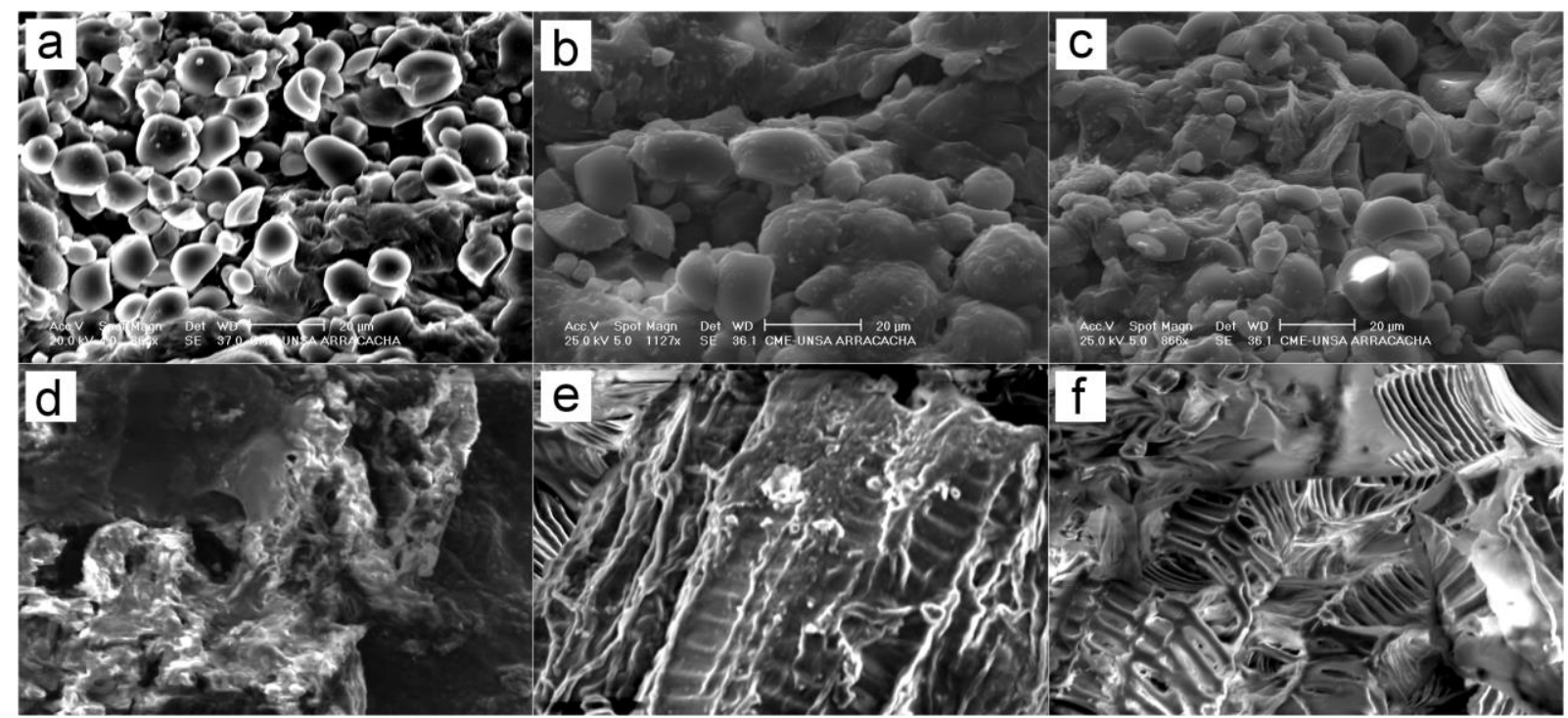

Figure 7. Micro-photographs of arracacha starch granules after a) 3, b) 4, c) 5, d) 6, e) 20 and f) 28 minutes 
Sensory evaluation and optimal cooking time Oca samples subjected to a cooking time of 28 minutes had better scores in acceptability and the rest of aspects, so this time was considered as the most suitable for cooking, reaching a temperature of $90.9^{\circ} \mathrm{C}$ in the center (Table 2). Olluco samples submitted to 29 minutes of cooking obtained higher scores of taste (more intense taste), with no significant difference in the other sensory aspects (Table 3 ). The isaño had a shorter optimum cooking time (24 - 25 minutes) considering acceptability (Table 4), while the most suitable time for the arracacha was 28 minutes considering flavor (Table 5). The shape and composition of the isaño would have favoured heat transfer, since the internal temperature is similar to that of the other samples that required more cooking time.

Table 2. Average values of oca sensory evaluation at different cooking times

\begin{tabular}{|c|c|c|c|c|c|}
\hline Time $(\mathrm{min})$ & Internal temperature $\left({ }^{\circ} \mathrm{C}\right)$ & Taste & Appearance & Acceptability & Aroma \\
\hline 26 & 90.7 & $5.3^{\mathrm{bc}}$ & $4.7^{\mathrm{c}}$ & $6.0^{\mathrm{ab}}$ & $6.0^{\mathrm{a}}$ \\
\hline 27 & 90.8 & $5.7^{\mathrm{b}}$ & $6.0^{\mathrm{ab}}$ & $6.7^{\mathrm{ab}}$ & $6.6^{\mathrm{a}}$ \\
\hline 28 & 90.9 & $6.9^{\mathrm{a}}$ & $6.8^{\mathrm{a}}$ & $7.3^{\mathrm{a}}$ & $6.5^{\mathrm{a}}$ \\
\hline 29 & 91.2 & $4.6^{\mathrm{c}}$ & $5.3^{\mathrm{bc}}$ & $5.5^{\mathrm{b}}$ & $6.2^{\mathrm{a}}$ \\
\hline
\end{tabular}

Different letters in columns mean a significant difference ( $\mathrm{p}$-value $<0.05$ )

Table 3. Average values of olluco sensory evaluation at different cooking times

\begin{tabular}{|c|c|c|c|c|c|}
\hline Time $(\mathrm{min})$ & Internal temperature $\left({ }^{\circ} \mathrm{C}\right)$ & Taste & Appearance & Acceptability & Aroma \\
\hline 28 & 91.3 & $6.4^{\mathrm{ab}}$ & $6.4^{\mathrm{a}}$ & $6.1^{\mathrm{a}}$ & $6.7^{\mathrm{a}}$ \\
\hline 29 & 91.4 & $7.1^{\mathrm{a}}$ & $6.7^{\mathrm{a}}$ & $7.0^{\mathrm{a}}$ & $6.5^{\mathrm{a}}$ \\
\hline 30 & 91.6 & $6.4^{\mathrm{ab}}$ & $6.5^{\mathrm{a}}$ & $6.7^{\mathrm{a}}$ & $6.7^{\mathrm{a}}$ \\
\hline 31 & 91.8 & $5.9^{\mathrm{b}}$ & $5.9^{\mathrm{a}}$ & $6.1^{\mathrm{a}}$ & $6.3^{\mathrm{a}}$ \\
\hline
\end{tabular}

Different letters in columns mean a significant difference $(\mathrm{p}$-value $<0.05)$

Table 4. Average values of isaño sensory evaluation at different cooking times

\begin{tabular}{|c|c|c|c|c|c|}
\hline Time $(\min )$ & Internal temperature $\left({ }^{\circ} \mathrm{C}\right)$ & Taste & Appearance & Acceptability & Aroma \\
\hline 23 & 90.9 & $5.6^{\mathrm{a}}$ & $6.4^{\mathrm{a}}$ & $5.5^{\mathrm{ab}}$ & $4.8^{\mathrm{a}}$ \\
\hline 24 & 91.0 & $6.2^{\mathrm{a}}$ & $6.6^{\mathrm{a}}$ & $5.8^{\mathrm{a}}$ & $4.6^{\mathrm{a}}$ \\
\hline 25 & 91.1 & $5.9^{\mathrm{a}}$ & $6.5^{\mathrm{a}}$ & $5.8^{\mathrm{a}}$ & $4.5^{\mathrm{a}}$ \\
\hline 26 & 91.3 & $5.6^{\mathrm{b}}$ & $6.0^{\mathrm{a}}$ & $4.7^{\mathrm{b}}$ & $4.5^{\mathrm{a}}$ \\
\hline
\end{tabular}

Different letters in columns mean a significant difference (p-value $<0.05$ )

Table 5. Average values of arracacha sensory evaluation at different cooking times

\begin{tabular}{|c|c|c|c|c|c|}
\hline Time $(\min )$ & Internal temperature $\left({ }^{\circ} \mathrm{C}\right)$ & Taste & Appearance & Acceptability & Aroma \\
\hline 26 & 88.7 & $6.7^{\mathrm{b}}$ & $7.3^{\mathrm{a}}$ & $8.0^{\mathrm{a}}$ & $8.3^{\mathrm{a}}$ \\
\hline 27 & 89.0 & $7.4^{\mathrm{ab}}$ & $7.2^{\mathrm{a}}$ & $8.0^{\mathrm{a}}$ & $8.4^{\mathrm{a}}$ \\
\hline 28 & 89.1 & $7.7^{\mathrm{a}}$ & $7.7^{\mathrm{a}}$ & $8.3^{\mathrm{a}}$ & $8.4^{\mathrm{a}}$ \\
\hline 29 & 89.3 & $7.2^{\mathrm{ab}}$ & $7.6^{\mathrm{a}}$ & $8.0^{\mathrm{b}}$ & $8.3^{\mathrm{a}}$ \\
\hline
\end{tabular}

Different letters in columns mean a significant difference ( $\mathrm{p}$-value $<0.05$ )

These cooking times are lower than potatoes which required 35 minutes of cooking to reach an internal temperature of $96{ }^{\circ} \mathrm{C}$, when properly cooked (Langworthy, 1917). 
All internal temperatures reached during the optimal cooking time were higher than the gelatinisation temperature of the starch of the different crops. In the case of oca, the reported gelatinisation temperature ranges were 50.2 to $63.3{ }^{\circ} \mathrm{C}$ (Santacruz, 2002) and 56.2 to $66.1{ }^{\circ} \mathrm{C}$ (at 70\% humidity) (Torres et al., 2011), 52.81 to $67.88{ }^{\circ} \mathrm{C}$ (Valcárcel-Yamani et al., 2013) and 58.8 to $69.7^{\circ} \mathrm{C}$ (at $70 \%$ humidity) (Torres et al., 2011) for the olluco, and 51.85 to 65.22 ${ }^{\circ} \mathrm{C}$ (Valcárcel-Yamani et al., 2013) and 61.5 to $71.8{ }^{\circ} \mathrm{C}$ (at 70\% humidity) (Torres et al., 2011) for the isaño, all of which were determined by DSC. The gelatinisation temperature range of the Arracacha starch was reported from 60 to $95^{\circ} \mathrm{C}$ using the Brabender viscoamylograph

\section{CONCLUSIONS}

The morphology and size of the starch granules of four Andean crops (oca, olluco, isaño and arracacha) were determined. The size of the raw starch granules ranged from 9 $\mu \mathrm{m}$ to $38.2 \mu \mathrm{m}$ for oca, $4.48 \mu \mathrm{m}$ to $24.9 \mu \mathrm{m}$ for olluco, $4.45 \mu \mathrm{m}$ to $22.9 \mu \mathrm{m}$ for isaño, and 5.36 $\mu \mathrm{m}$ to $23.8 \mu \mathrm{m}$ for arracacha. These values were similar to those reported in the literature for the same crops, explaining the diversity of sizes due to differences in cultivars, harvest time and agricultural practices. In the case of arracacha, this study shows that the presence of cuboid and truncated starch granules is natural and not the result of a starch extraction treatment. When the samples were cooked with boiling water, the shape of the starch granules was lost and pastes were formed over
(Pérez et al., 1999), 68 to $95^{\circ} \mathrm{C}$ using the rapid viscoanalyser (RVA) (Pérez et al., 1998) and $54.12^{\circ} \mathrm{C}$ to $64.18^{\circ} \mathrm{C}$ and 54.6 to $65.8^{\circ} \mathrm{C}(70 \%$ humidity) using DSC (Torres et al., 2011). The internal temperature of the arracacha specimens at the optimum cooking time (89.1 ${ }^{\circ} \mathrm{C}$ ) was lower than that of the other samples. It has been pointed out that the low gelatinisation temperature of this starch contributes to facilitating cooking and high digestibility (Albano et al., 2014). Thus, our results confirmed that there was no relationship between gelatinization temperature and internal cooking temperature that produced the best sensory results.

5 minutes after cooking, with the starch granules remaining in shape longer.

The cooking time of the samples considered as optimal by sensory evaluation allowed to reach temperatures in the geometric centre higher than the starch gelatinisation temperatures reported for each sample, confirming that gelatinisation of starch granules is not an adequate parameter to estimate sensorial acceptance. During cooking, it was observed that the arracacha raised its internal temperature more slowly than the other samples. The isaño and olluco samples had a similar behavior among them. Further research is recommended to take advantage of the different characteristics of starch granules in the samples studied, as well as the effect of tuber shape on heat transfer during cooking.

\section{ACKNOWLEDGEMENTS}

The authors would like to express their gratitude to Mr. Juan José Alca Machaca for his support and suggestions of sources to discuss the results.

\section{REFERENCES}

1. Albano, K.M., Franco, C.M.L., \& Telis, V.R.N. (2014). Rheological behavior of Peruvian carrot starch gels as affected by temperature and concentration. Food Hydrocolloids, 40, 30-43. DOI: 10.1016/j.foodhyd.2014.02.003

2. Bianco, M., \& Sachs, C. (1998). Growing Oca, Ulluco, and Mashua in the Andes: Socioeconomic differences in cropping practices. Agriculture and Human Values, 15(3), 267-280. DOI: 10.1023/A:1007572203541

3. Biondi, J., Zorrilla, C., Manrique, I., Arbizu, C., Roca, W., Medina, T., Seminario, J., Quispe, J., Tay, D. \& Blas, R. (2009). Genetic diversity of arracacha (Arracacia xanthorrhiza) in Peru. In Tropical roots and tubers in a changing climate: A convenient opportunity for the world. XV Triennial symposium of the international society for tropical root crops, 2 November 2009 (pp. 60-66). Lima, Perú: International Society for Tropical Root Crops - Peru Branch. Retrieved 
September

23 ,

2017 ,

from

http://www.istrc.org/images/Documents/Symposiums/Fifthteenth/s2_biondi2.pdf

4. Busch, J.M., Sangketkit, C., Savage, G.P., Martin, R.J., Halloy, S., \& Deo, B. (2000). Nutritional analysis and sensory evaluation of ulluco (Ullucus tuberosus Loz) grown in New Zealand. Journal of the Science of Food and Agriculture, 80(15), 2232-2240. DOI: 10.1002/10970010(200012)80:15<2232::AID-JSFA785>3.0.CO;2-N

5. Cortella, A.R., \& Pochettino, M.L. (1995). Comparative Morphology of Starch of Three Andean Tubers. Starch/Stärke, 47(12), 455-461. DOI: 10.1002/star.19950471202

6. Cruz, G., Ribotta, P., Ferrero, C., \& Iturriaga, L. (2016). Physicochemical and rheological characterization of Andean tuber starches: Potato (Solanum tuberosum ssp. Andigenum), Oca (Oxalis tuberosa Molina) and Papalisa (Ullucus tuberosus Caldas). Starch/Stärke, 68(11-12), 1084-1094. DOI: 10.1002/star.201600103

7. Flores, H.E., Walker, T.S., Guimarães, R.L., Bais, H.P., \& Vivanco, J.M. (2003). Andean root and tuber crops: Underground rainbows. HortScience, 38(2), 161-167.

8. Goldner, M.C., Pérez, O.E., Pilosof, A.M.R., \& Armada, M. (2012). Comparative study of sensory and instrumental characteristics of texture and color of boiled under-exploited Andean tubers. LWT - Food Science and Technology, 47(1), 83-90. DOI: 10.1016/j.lwt.2011.12.031

9. Heinze, P. H. (1955). Cooking Quality and Compositional Factors of Potatoes of Different Varieties from Several Commercial Locations. USDA Technical Bulletin. Washington D.C.: United States Department of Agriculture.

10.Hernández-Lauzardo, A.N., Méndez-Montealvo, G., Velázquez del Valle, M.G., Solorza-Feria, J., \& Bello-Pérez, L.A. (2004). Isolation and Partial Characterization of Mexican Oxalis tuberosa Starch. Starch/Stärke, 56(8), 357-363. DOI: 10.1002/star.200300235

11.Hodge, W.H. (1954). The edible arracacha-A little-known root crop of the Andes. Economic Botany, 8(3), 195-221. DOI: 10.1007/BF02984890

12.Jimenez, M.E., Rossi, A., \& Sammán, N. (2015). Health properties of oca (Oxalis tuberosa) and yacon (Smallanthus sonchifolius). Food \& Function, 6(10), 3266-3274. DOI: 10.1039/C5FO00174A

13.King, S.R., \& Gershoff, S.N. (1987). Nutritional evaluation of three underexploited andean tubers: Oxalis tuberosa, (Oxalidaceae), Ullucus tuberosus (Basellaceae), and Tropaeolum tuberosum (Tropaeolaceae). Economic Botany, 41(4), 503-511. DOI: 10.1007/BF02908144

14.Langworthy, C.F. (1917). Potatoes, sweet potatoes and other starchy roots as food. Washington, D.C.: United States Department of Agriculture. DOI: 10.5962/bhl.title.108382

15.Malice, M. (2009). Genetic diversity and structure of three Andean tubers: Oxalis tuberosa Molina, Ullucus tuberosus Caldas and Tropaeolum tuberosum Ruiz \& Pav. Ph.D. Thesis, Gembloux Agricultural University, Gembloux, Belgium.

16.Medina, O.J., Pardo, O.H., \& Ortiz, C.A. (2012). Modified Arracacha starch films Characterization and its Potential Utilization as Food Packaging. Vitae, 19(2), 186-196.

17.Pérez, E.E., Borneo, R., Melito, C.G., \& Tovar, J. (1999). Chemical, physical and morphometric properties of Peruvian carrot (Arracacia xanthorrhiza B.) starch. Acta Cientifica Venezolana, 50(4), 240-244.

18.Pérez, E.E., Breene, W.M., \& Bahnassey, Y.A. (1998). Gelatinization Profiles of Peruvian Carrot, Cocoyam and Potato Starches as Measured with the Brabender Viscoamylograph, Rapid ViscoAnalyzer, and Differential Scanning Calorimeter. Starch/Stärke, 50(1), 14-16. DOI: 10.1002/(SICI)1521-379X(199801)50:1<14::AID-STAR14>3.0.CO;2-P

19. Quiroga Ledezma, C.C. (2009). Caracterización fisicoquímica de tres fuentes subutilizadas de almidón de la región andina de Bolivia. UPB Investigación \& Desarrollo, 1(9), 72-87.

20.R Development Core Team. (2008). R: A language and environment for statistical computing [computer software]. Vienna, Austria.

21.Rocha, T.S., Cunha, V.A.G., Jane, J.-1., \& Franco, C.M.L. (2011). Structural Characterization of Peruvian Carrot (Arracacia xanthorrhiza) Starch and the Effect of Annealing on Its Semicrystalline Structure. Journal of Agricultural and Food Chemistry, 59(8), 4208-4216. DOI: $10.1021 /$ jf104923m 
22.Rocha, T.S., Demiate, I.M., \& Franco, C.M.L. (2008). Características estruturais e físico-químicas de amidos de mandioquinha-salsa (Arracacia xanthorrhiza). Ciência e Tecnologia de Alimentos, 28(3), 620-628. DOI: 10.1590/S0101-20612008000300018

23.Santacruz, S. (2002). Three underutilised sources of starch from the Andean region in Ecuador Part I. Physico-chemical characterisation. Carbohydrate Polymers, 49(1), 63-70. DOI: 10.1016/S0144-8617(01)00305-8

24.Santacruz, S. (2004). Characterisation of starches isolated from Arracacha xanthorriza, Canna edulis and Oxalis tuberosa and extracted from potato leaf. PhD Thesis, Swedish University of Agricultural Sciences, Uppsala, Sweden.

25.Santos, F.F., \& Hermann, M. (1994). Processing arracacha (Arracacia xantorrhiza Bancroft) in Brazil. In Proceedings of the tenth symposium of the international society for tropical root crops, 23-29 October 1994 (pp. 1-10). Salvador, Bahia, Brazil: ISTRC. Retrieved September 23, 2017, from

http://www.istrc.org/images/Documents/Symposiums/Tenth/51processing_arracacha_in_brazil.pdf

26. Surco Laos, F.A. (2004). Caracterización de almidones aislados de tuberculos andinos: mashua (Tropaeolum tuberosum), Oca (Oxalis tuberosa), Olluco (Ullucus tuberosus) para su aplicación tecnológica. Master Thesis, Universidad Nacional Mayor de San Marcos, Lima, Peru.

27.Takeiti, C., Fakhouri, F., Ormenese, R., Steel, C., \& Collares, F. (2007). Freeze-thaw Stability of Gels Prepared from Starches of Non-conventional Sources. Starch/Stärke, 59(3-4), 156-160. DOI: 10.1002/star.200600544

28.Torres, F.G., Troncoso, O.P., Díaz, D.A., \& Amaya, E. (2011). Morphological and thermal characterization of native starches from Andean crops. Starch/Stärke, 63(6), 381-389. DOI: 10.1002/star.201000155

29.Valcárcel-Yamani, B., Rondán-Sanabria, G.G., \& Finardi-Filho, F. (2013). The physical, chemical and functional characterization of starches from Andean tubers: oca (Oxalis tuberosa Molina), olluco (Ullucus tuberosus Caldas) and mashua (Tropaeolum tuberosum Ruiz \& Pavón). Brazilian Journal of Pharmaceutical Sciences, 49(3), 453-464. DOI: 10.1590/S1984-82502013000300007 